\title{
Environmental control of seasonal and inter-annual variations of periphytic biomass in a North Iberian stream
}

\author{
O. Izagirre*, A. Elosegi
}

Department of Plant Biology and Ecology. Faculty of Science and Technology. University of the Basque Country, P.O. Box 644, 48080 Bilbao, Spain.

During 2001 - 2002, we studied periphytic biomass at 5 sites along the Agüera stream (Northern Iberian Peninsula), and compared the results to those from two previous researches (1990 - 1991 and 1992 - 1993). Sampling sites showed large differences in cover, conductivity and nutrient contents, as well as some inter-annual differences, resulting from changes in discharge and in human activities. Most environmental variables showed low seasonality, main variations being produced by floods. Solar radiation changed little during 2001 - 2002, because of the coincidence of a sunny winter followed by a cloudy summer, and seasonal differences in riparian cover resulted in more sunlight reaching the streambed of closed sites during winter, and small differences at the open ones. The growth and abscission of riparian leaves results in a strong light regime at the closed sites, with more sunlight during winter, but this pattern changes from year to year, depending on the weather. Spatial differences and highest values of periphytic biomass were much lower than those measured in 1990 - 91, because of contrasting weather patterns. Variables controlling periphytic biomass in the Agüera change from reach to reach. At open sites flow is the main temporal controller, whereas at closed sites the effects of light availability prevail, thus giving more similar seasonal patterns from year to year. Nutrients seem to play a minor role in temporal variations.

Keywords : periphyton, Agüera stream, seasonal variations, interannual variations.

\section{Introduction}

Periphytic algae are the main primary producers in many temperate streams. Their abundance is controlled by environmental factors like nutrient content (Biggs 2000), temperature (Eulin \& Le Cohu 1998), light availability (DeNicola et al. 1992), grazing pressure (Steinman et al. 1990), discharge (Mosisch \& Bunn 1997), and substrate stability (Biggs \& Gerbeaux 1993). Some of these factors (e.g., light and water temperature) show a more or less regular seasonality, whereas others like discharge can change in a more unpredictable way. As a result of the interactions between these and other factors, periphytic biomass can show complex spatial and temporal patterns (Biggs 1995, Biggs et al. 1998). For instance, at open reaches light

\footnotetext{
* Corresponding author :

E-mail: gvbizigo@lg.ehu.es
}

availability is greater during summer, because of the longer daylight period, whereas at closed reaches under deciduous forest it can be greater during winter (Hill et al. 2001). Thus, seasonal dynamics of periphyton can differ on a reach basis depending, among others, on the nature and extent of riparian cover.

In flood prone rivers, discharge can control periphyton development, overriding spatial and temporal differences in light or nutrients. Spates are disturbances that slough and reset algal biomass to low values, and periphytic communities can recover more or less, depending on the length of periods between floods and on the light and nutrient levels available during these periods (Elósegui \& Pozo 1998). In torrential systems, periphytic biomass can exhibit large inter-annual variations as a result of differences in rainfall patterns (Uehlinger et al. 1996, Uehlinger 2000). Therefore, in order to compare periphyton abundance between streams, it is essential to have an idea of interannual 
variability in discharge, and of its effects on periphyton. Nevertheless, most papers on periphyton deal with data from only one year, thus making comparisons difficult.

In this paper we describe seasonal patterns of periphyton abundance at 5 sites along the Agüera, a 3rdorder stream, discuss the environmental factors responsible for these patterns, and compare periphytic biomass in three years of contrasting hydrology. Our hypothesis is that differences in flood frequency and timing will result in different patterns of periphytic biomass depending on reach canopy cover.

\section{Study area}

The Agüera, a 30-km-long stream between Biscay and Cantabria (northern Spain), drains a $145 \mathrm{~km}^{2}$ basin (Fig. 1), being mount Burgueño (1,044 $\mathrm{m}$ a.s.l.) the highest elevation. Lithology is mainly siliceous, except

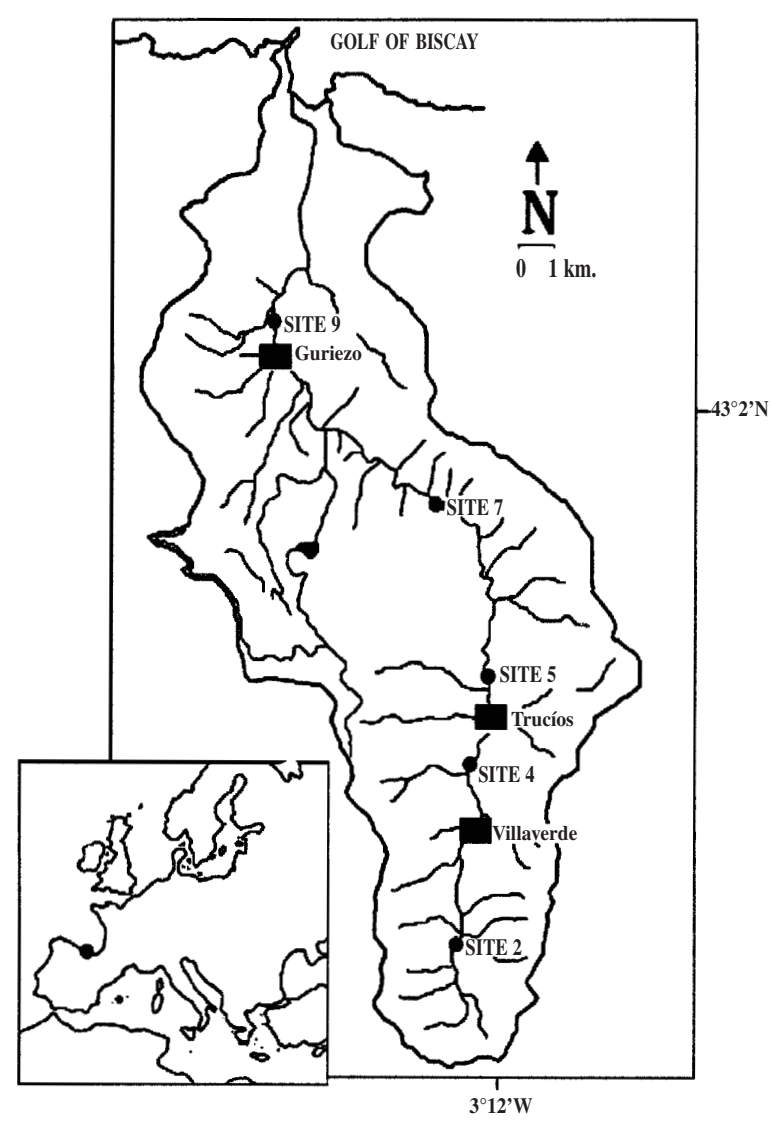

Fig. 1. The Agüera stream basin. Location of the main urban areas and sampling sites. in a central calcareous belt. Climate is humid oceanic with an average annual precipitation of $1500 \mathrm{~mm}$, mainly in form of rain, and regularly distributed throughout the year. Mean monthly temperatures range from $9.8^{\circ} \mathrm{C}$ in January to $18.5^{\circ} \mathrm{C}$ in August. Because of its steep, short channels, the Agüera is a flashy stream, and therefore, although annual rainfall is fairly constant, the number of floods, and especially the duration of flood-free periods can change markedly from year to year (Elosegi et al. 2002).

Population density is low and settlement disperse, the largest villages being Villaverde (pop 426), Trucíos (pop 540) and Guriezo (pop 1715). The main human activities are forestry, livestock farming and agriculture. Large tracts of native deciduous forest remain in the headwaters, whereas most steep areas in the rest of the basin have been planted with exotic eucalyptus or pine. The uplands are covered by unimproved pasture, and the lowlands by meadows and arable land. Most reaches of the Agüera stream are covered by deciduous riparian forests, although their extent and maturity is highly variable (Elósegui \& Pozo 1998, Díez et al. 2001). New leaves grow in April, and abscission occurs mainly in November.

Physico-chemical characteristics of the water reflect the geology and land-use of different parts of the basin. At the headwaters conductivity and nutrient contents are low, but they increase sharply when the stream runs through Villaverde and Trucíos, in the calcareous part of the basin (Elósegui \& Pozo 1994). Further downstream there is a segment of low nutrient inputs where self-purification causes an improvement in water quality (Elósegui et al. 1995). Finally, the stream runs through Guriezo, and there urban sewage causes an increase in nutrient content.

Previous studies have shown that during low flow periods the spatial distribution of periphyton is determined by the nutrient content and light availability, whereas temporal variations are mainly controlled by floods (Elósegui \& Pozo 1998, López de Luzuriaga 1995). In the Agüera stream, discharges below $30 \mathrm{~m}^{3} / \mathrm{s}$ measured at the mouth do not affect very much to periphytic biomass, whereas larger floods scour most of it (Elósegui \& Pozo 1998), presumably because this is the threshold for bed-moving spates.

\section{Methods}

\section{Site selection}

Five sites were selected along the main channel of the Agüera stream (Fig. 1), looking for as broad a ran- 
ge of environmental conditions as possible, and repeating whenever possible the sites of two previous studies, one in 1990-91 (Elósegui \& Pozo 1998), and the other in 1992-93 (López de Luzuriaga 1995). Site 2, at the headwaters, has low nutrient contents and a dense canopy of alder, oak and hazelnut; it was also studied by Elósegui \& Pozo (1998). Site 4, below Villaverde, has higher nutrient concentrations and is covered by a dense riparian forest; site 4 by Elósegui \& Pozo (1998) was just a reach adjacent to the present site 4 , more open, but it could not be sampled in the present work because of sand and gravel accumulation. Site 5, located below Trucíos, is one of the most open reaches of the main stream axis, and also has high nutrient concentrations. Site 7 has also relatively open canopy, although the banks are covered by forests, and has low nutrient contents; site 9, below Guriezo, was described in previous works as organically polluted, with abundant sewage fungus, and a very dense riparian coverage. Sites 5, 7 and 9 were studied by both Elósegui \& Pozo (1998) and López de Luzuriaga (1995).

\section{Sampling}

Periphyton was sampled monthly during one year, from September 2001 to September 2002. A surface of $100 \mathrm{~m}^{2}$ was delimited in a riffle at each site and ten stones were collected at random. All periphytic material was scraped from an area of $18.85 \mathrm{~cm}^{2}$ per stone, using scalpels, toothbrushes and Pasteur pipettes, and was stored in plastic containers. Water samples for chemical analysis were also collected. All these were taken to the laboratory in an ice box and frozen until analysis. Additionally, water temperature, $\mathrm{pH}(\mathrm{pH}$ meter Hanna HI 9025), oxygen concentration (oxymeter WTW OXI 96), and conductivity (conductivimeter WTW LF 90) were measured.

\section{Laboratory procedures}

Periphyton samples were homogenised with a domestic blender. One subsample was used to determine ash-free dry mass (AFDM), drying at $105^{\circ} \mathrm{C}$ for $24 \mathrm{~h}$ and ashing at $500^{\circ} \mathrm{C}$ for $4 \mathrm{~h}$. Another subsample was used to measure periphytic chlorophyll $a$ content spectrophotometrically after extraction in hot ethanol (Sartory \& Grobbelaar 1984). Nitrate, nitrite and ammonia in water were measured with TRAACS 800 auto analyser. Phosphate was measured by the stannous chloride method (APHA, 1992) on a Shimadzu UV-1603 spectrophotometer.

\section{Data analysis}

Chlorophyll $a$ and AFDM values at each site and date were compared using two-way ANOVAs and Tu-
key/Krammer Post Hoc Test. Periphytic growth rates between two consecutive sampling dates were calculated dividing the difference of periphytic biomass or chlorophyll $a$ content by time elapsed.

To determine the environmental factors controlling periphyton in 2001 - 2002, we performed multiple Stepwise regressions between periphytic biomass and variables associated to discharge, light and nutrients. Because of contrasting temporal patterns, we performed two multiple regressions, one with the closed reaches (2, 4 and 9) and another with the open ones (5 and 7). Another stepwise multiple regression was performed for all sites, relating periphytic growth, light and nutrient contents only during increase phases. Discharge was daily measured by the Spanish Northern Hydrographical Confederation at their gauging station below Guriezo (site 9). To have an idea of the effect of spates on periphyton, we computed flow indexes following Shortreed and Stockner (1983), for periods of 30 days prior to sampling dates. It was calculated summing each day's maximum daily flow divided by the respective number of days prior to sampling ( $\sum \mathrm{Fi} / \mathrm{i}$ ). High flow indexes indicate high discharges occurring close before a given sampling date. Solar radiation was continuously measured by the Spanish Meteorological Institute at San Sebastian. To have an estimate of the radiation reaching the stream during the periods between sampling dates, we corrected these data taking in account canopy cover at each site. This was measured taking several vertical photographs at each sampling site with a wide-angle lens, scanning the photographs, increasing their contrast to get black (covered) and white (uncovered sky) images, and analysing these images with NIH 1.55 software. Radiation data were so corrected for cover values taken in February (winter cover, from December to March) and early October (summer cover, from April to November).

Lack of data made impossible to repeat this kind of analyses to compare inter-annual variations: in 199091 there were no data on light availability, and in 1992 - 93 we lacked data on water chemistry. We did analyse daily discharges from 1990 to 2002 (number of spates, annual average flow, length of low flow periods) and calculated predictability, constancy and contingency of peak floods (Colwell 1974) to measure inter-annual variability of the discharge regime. Predictability is greatest when the same monthly pattern is repeated in all years; constancy is greatest when the stage is the same for all months and contingency greatest when the stage is different for each month but the pattern is the same for all years. Differences in flow regime between 1990 - 1991, 1992 - 1993 and 2001 - 
2002 were assessed comparing flow indexes with Student's Paired t Test. Inter-annual variations of periphyton biomass were studied comparing periphytic biomass values of 1990 - 1991 (Elósegui \& Pozo 1998), 1992 - 1993 (López de Luzuriaga 1995) and 2001 2002 (present data) at sites 5, 7 and 9, using one-way ANOVA and the Tukey/Krammer Post Hoc Test.

\section{Results}

\section{Environmental variables}

Water characteristics showed marked spatial differences (Table 1). Average $\mathrm{pH}$ ranged from 7.4 at site 2 to 7.8 at sites 5 and 7 , where values over 8 were common. Conductivity was lowest at site 2 (average $146 \mu \mathrm{S} / \mathrm{cm}$ ), and averaged over $200-240 \mu \mathrm{S} / \mathrm{cm}$ at the rest of sites. Nutrients also showed broad spatial differences. Site 2 was the most oligotrophic one, with average total nitrogen concentrations of $488 \mu \mathrm{g} N / 1$ and phosphate concentrations of $11 \mu \mathrm{g} / \mathrm{P} / \mathrm{l}$. Nutrient concentrations increased at site $4,(872 \mu \mathrm{g} \mathrm{N} / 1$ and $69 \mu \mathrm{g} \mathrm{P} / \mathrm{l})$, and peaked at site $5(1237 \mu \mathrm{g} \mathrm{N} / \mathrm{l}$ and $82 \mu \mathrm{g}$ $\mathrm{P} / \mathrm{l})$. There was a marked decrease downstream from Trucíos, although phosphate averaged somewhat higher values at site 9 than at site 7 (37 vs $22 \mu \mathrm{g} \mathrm{P} /$, respectively).

Canopy cover varied markedly between sites and between seasons (Table 1). The most closed sites were 9,4 and 2, with a canopy cover of 55\%, 53\% and 56\% respectively in winter, and $81 \%, 82 \%$ and $70 \%$ in summer. The most open sites were 7 (24\% in winter $36 \%$ in summer) and 5 (16 and 48\%). These differences in canopy cover, combined with changes in day length and weather, resulted in large differences in radiation reaching the stream bed. Clear weather was prevalent during much of the winter, whereas the summer was very cloudy. Therefore, despite longer days in summer total daily radiation averaged $4724 \mathrm{~kJ} / \mathrm{m}^{2}$ during winter (December to March) a value very close to the $4824 \mathrm{~kJ} / \mathrm{m}^{2}$ registered for summer (April to November). These differences were increased by the canopy cover, and for all sites the daily radiation estimated to reach the stream bed was lower during summer than during winter (Student $\mathrm{t}$ test, $\mathrm{p}<0.05)$, differences being greatest at sites 4 and 9 (Table 1).

Discharge was very low from September to October 2001 (Fig. 2); from November on, some small flow rises below the bed-moving threshold $\left(30 \mathrm{~m}^{3} / \mathrm{s}\right)$ were registered. A flood of $61.69 \mathrm{~m}^{3} / \mathrm{s}$ occurred in early May, followed by 3 months of low discharge, and a large spate over $90 \mathrm{~m}^{3} / \mathrm{s}$ occurred at the end of August.

\section{Seasonal periphyton dynamics}

Periphytic AFDM showed strong spatial and temporal changes (Fig. 2). At site 2, low values (2.1 $19.5 \mathrm{~g} / \mathrm{m}^{2}$ ) were registered throughout the study period. At sites 4 and 9 maxima were registered in March (up to $33.9 \mathrm{~g} / \mathrm{m}^{2}$ and $36 \mathrm{~g} / \mathrm{m}^{2}$ respectively), in absence of leaves, and summer values were lower (3.7 - 6.6 $\mathrm{g} / \mathrm{m}^{2}$ at site 4 and $4.7-17.2 \mathrm{~g} / \mathrm{m}^{2}$ at site 9$)$. At the open

Table 1. Mean values (with standard error) of some physical and chemical variables at 5 sampling sites $(2,4,5,7,9)$ of the Agüera stream $(n=12$; canopy cover $n=10)$.

\begin{tabular}{|c|c|c|c|c|c|c|}
\hline Sites & & 2 & 4 & 5 & 7 & 9 \\
\hline $\mathrm{pH}$ & & $\begin{array}{c}7.4 \\
(6.98-7.78)\end{array}$ & $\begin{array}{c}7.5 \\
(7.13-8.21)\end{array}$ & $\begin{array}{c}7.8 \\
(7.61-8.45)\end{array}$ & $\begin{array}{c}7.8 \\
(7.23-8.15)\end{array}$ & $\begin{array}{c}7.6 \\
(7.35-7.90)\end{array}$ \\
\hline Conductivity $(\mu \mathrm{S} / \mathrm{cm})$ & & $\begin{array}{c}146.3 \\
(97-242)\end{array}$ & $\begin{array}{c}203.4 \\
(131-370)\end{array}$ & $\begin{array}{c}242.0 \\
(179-370)\end{array}$ & $\begin{array}{c}230.1 \\
(181-290)\end{array}$ & $\begin{array}{c}213.9 \\
(161-306)\end{array}$ \\
\hline Nitot $(\mu \mathrm{g} N /)$ & & $\begin{array}{c}487.8 \\
(73.9-993.2)\end{array}$ & $\begin{array}{c}872.3 \\
(190-1622.9)\end{array}$ & $\begin{array}{c}1236.7 \\
(734.6-2165.6)\end{array}$ & $\begin{array}{c}903.5 \\
(499.8-1315.1)\end{array}$ & $\begin{array}{c}835.6 \\
(60.8-1360.4)\end{array}$ \\
\hline Phosphate ( $\mu \mathrm{g}$ P/) & & $\begin{array}{c}11.3 \\
(1.3-46.3)\end{array}$ & $\begin{array}{c}68.9 \\
(12.0-237.8)\end{array}$ & $\begin{array}{c}81.5 \\
(14.9-227.9)\end{array}$ & $\begin{array}{c}21.8 \\
(6.2-39.9)\end{array}$ & $\begin{array}{c}37.1 \\
(0.0-115,4)\end{array}$ \\
\hline \multicolumn{7}{|l|}{ Canopy cover (\%) } \\
\hline Winter & & 56 & 53.2 & 16.5 & 24.2 & 55.5 \\
\hline Summer & & 70.1 & 82 & 48 & 36.4 & 81.1 \\
\hline \multicolumn{7}{|c|}{ Total daily radiation $\left(\mathbf{k J} / \mathrm{m}^{2}\right)$} \\
\hline & At the canopy & & & & & \\
\hline Winter & $\begin{array}{c}4724 \\
(100-9780)\end{array}$ & $\begin{array}{c}2078 \\
(44.00-4303)\end{array}$ & $\begin{array}{c}2210 \\
(46.80-4577)\end{array}$ & $\begin{array}{c}3944 \\
(83.50-8166)\end{array}$ & $\begin{array}{c}3580 \\
(75.80-7413)\end{array}$ & $\begin{array}{c}2102 \\
(44.50-4352)\end{array}$ \\
\hline Summer & $\begin{array}{c}4824 \\
(140-9920)\end{array}$ & $\begin{array}{c}1442 \\
(41.86-2966)\end{array}$ & $\begin{array}{c}868 \\
(25.20-1785)\end{array}$ & $\begin{array}{c}2508 \\
(72.80-5158)\end{array}$ & $\begin{array}{c}3068 \\
(89.04-6309)\end{array}$ & $\begin{array}{c}911 \\
(26.46-1875)\end{array}$ \\
\hline
\end{tabular}


reaches, 5 and 7 , a peak of periphytic biomass occurred in October $2001\left(26.1 \mathrm{~g} / \mathrm{m}^{2}\right.$ and $40.0 \mathrm{~g} / \mathrm{m}^{2}$ respectively) but lower values were found in November; during winter there was an increase of periphytic biomass, more sustained at site 7 , and another peak was reached in March $2002\left(43.1 \mathrm{~g} / \mathrm{m}^{2}\right.$ at site 5 and $25.5 \mathrm{~g} / \mathrm{m}^{2}$ at site 7); in April biomass decreased again although discharge was low, and values below $5 \mathrm{~g} / \mathrm{m}^{2}$ were registered after the spate of May; in summer periphytic biomass peaked in July $\left(50.7 \mathrm{~g} / \mathrm{m}^{2}\right.$ at site $5,35.4$ $\mathrm{g} / \mathrm{m}^{2}$ at site 7 ), but decreased to values below $4 \mathrm{~g} / \mathrm{m}^{2}$ with the flood of late August.

Differences in periphytic biomass were significant for both date and site, as well as for date $\mathrm{x}$ site interaction (two-way ANOVA on log-transformed data, Table 2). Biomass was significantly lower at site 2 than at site 4 , and at this site significantly lower than at sites 9 , 5 and 7. Stepwise regressions between periphytic biomass and environmental variables of the closed sites did not include any of the environmental factors in the model. Stepwise regressions of the open sites included flow index as significant factor, but excluded radiation and $\mathrm{N}$ and $\mathrm{P}$ concentrations (Table 3 ).

Periphytic chlorophyll $a$ contents also showed important differences between sites (Fig. 3). These differences were similar to those occurring with AFDM, but winter maxima occurred in general earlier and were in general higher. Values were always low at site 2 $\left(0.001-28.049 \mathrm{mg} / \mathrm{m}^{2}\right)$, peaked during winter at sites 4 and 9 (116.2 - $294.9 \mathrm{mg} / \mathrm{m}^{2}$ respectively), and at sites 5 and 7 peaks were registered both in winter and summer $\left(201.9 \mathrm{mg} / \mathrm{m}^{2}\right.$ and $196.9 \mathrm{mg} / \mathrm{m}^{2}$ respectively for winter, $181.7 \mathrm{mg} / \mathrm{m}^{2}$ and $158.6 \mathrm{mg} / \mathrm{m}^{2}$ for summer). Stepwise regressions of the closed sites showed chlorophyll $a$ to be controlled mainly by solar radiation, as flow index and nutrient contents were rejected from the model. In the open sites flow index and radiation were included, but the model rejected nutrient content (Table 3).

Periphytic growth-rate at the open sites (in terms of both biomass and chlorophyll $a$ ) was limited by the

Table 2. Results of the two-way ANOVA of AFDM and chlorophyll $a$ in the five sites at different dates. Summary of the Tukey/Krammer Post Hoc Test, the underlined sites refer to non-significant differences. Values were log-transformed before the analysis.

\begin{tabular}{lccccccc} 
& \multicolumn{4}{c}{ AFDM } & \multicolumn{3}{c}{ Chlorophyll $a$} \\
\cline { 2 - 7 } ANOVA & DF & F & P & DF & F & P \\
Date & 11 & 20,426 & $<0.0001$ & 11 & 68,553 & $<0.0001$ \\
Site & 4 & 24,245 & $<0.0001$ & 4 & 85,131 & $<0.0001$ \\
Date * site. & 44 & 2,944 & $<0.0001$ & 44 & 5,123 & $<0.0001$ \\
TUKEY-KRAMMER & \multicolumn{4}{c}{$24 \underline{957}$} & & & $24 \underline{795}$ \\
\hline
\end{tabular}

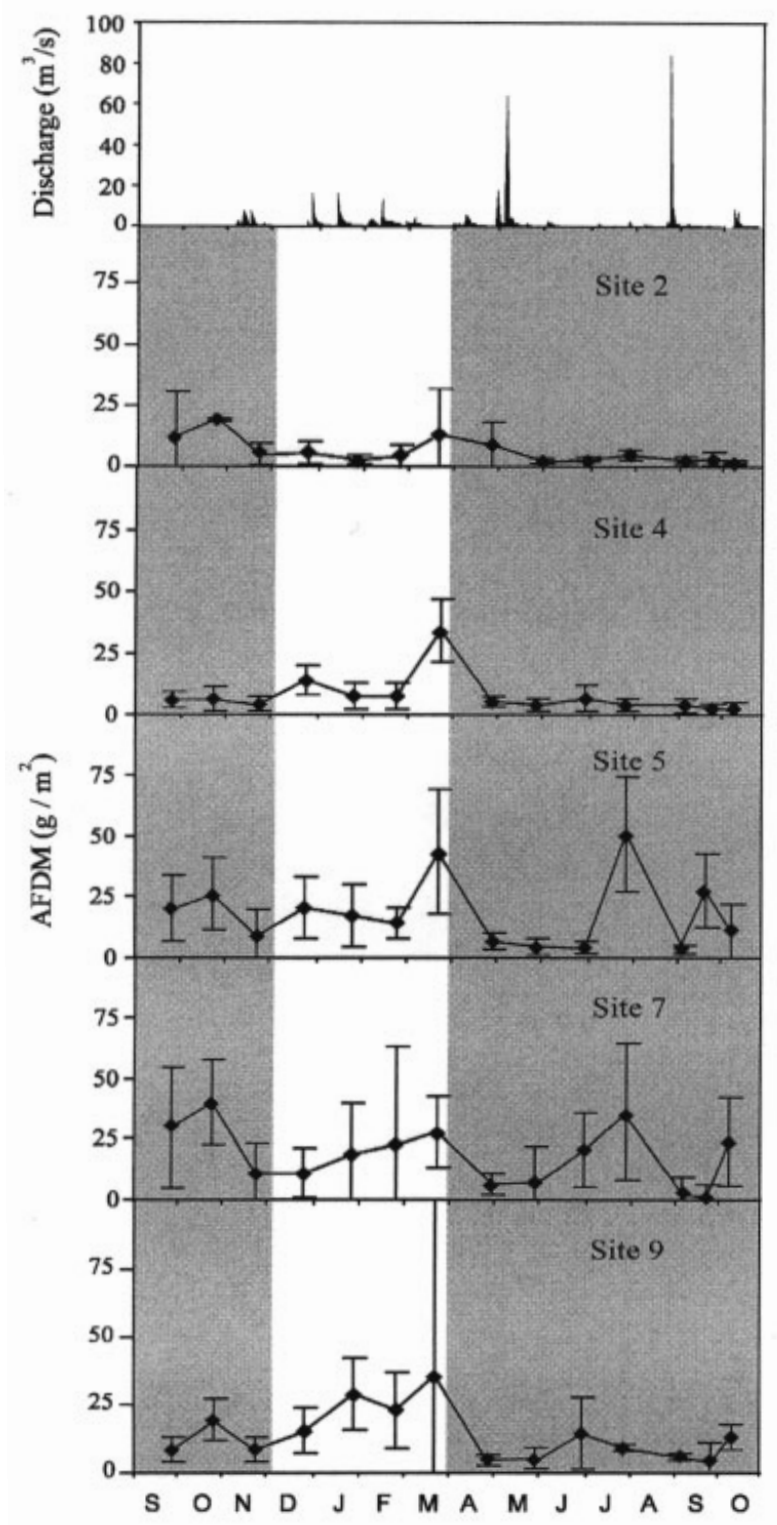

Fig. 2. Periphytic biomass at sites 2, 4, 5, 7 and 9 in the Agüera stream, from September 2001 to October 2002. Grey areas mark the period when the riparian forest has leaves. Discharge values registered at site 9 are shown at top.

flow index, as shown by stepwise regressions. At the closed sites no one of the environmental variables was included. During increase phases AFDM growth was positively related to phosphate content (Table 3 ). AFDM growth peaked in September-October at site 7 $\left(0.37 \mathrm{~g} / \mathrm{m}^{2} \mathrm{~d}\right)$ and in February - March at the rest of sites, being larger at sites 4 and $5\left(0.95 \mathrm{~g} / \mathrm{m}^{2} \mathrm{~d}\right.$, $1.03 \mathrm{~g} / \mathrm{m}^{2} \mathrm{~d}$ ) (Fig. 4). At the open sites growth also pea- 
Table 3. Factors controlling periphyton biomass in the Agüera stream. Results of stepwise multiple regression analysis.

\begin{tabular}{|c|c|c|c|c|c|c|c|}
\hline & Dependent variable & $r^{2}$ & $\begin{array}{l}\text { Independent } \\
\text { variable }\end{array}$ & $\begin{array}{c}\text { Partial } \\
\text { correlation }\end{array}$ & Coefficient & $\begin{array}{l}\text { Std. } \\
\text { error }\end{array}$ & $\begin{array}{l}\text { Sign. } \\
\text { level }\end{array}$ \\
\hline \multirow[t]{16}{*}{ Closed sites } & AFDM & & Ptot & 0.313 & - & - & - \\
\hline & & & Ntot & -0.283 & - & - & - \\
\hline & & & $\begin{array}{l}\text { Flow index } \\
\text { ( } 30 \text { days) }\end{array}$ & -0.243 & - & - & - \\
\hline & & & $\begin{array}{l}\text { Radiation } \\
\text { (30 days) }\end{array}$ & 0.101 & - & - & - \\
\hline & Chlorophyll a & 0.18 & $\begin{array}{l}\text { Radiation } \\
\text { (30 days) }\end{array}$ & 0.429 & 0.016 & 0.006 & 0.009 \\
\hline & & & Ntot & 0.138 & - & - & - \\
\hline & & & Ptot & 0.122 & - & - & - \\
\hline & & & $\begin{array}{l}\text { Flow index } \\
\text { (30 days) }\end{array}$ & -0.032 & - & - & - \\
\hline & AFDM growth rate & & Ptot & 0.24 & - & - & - \\
\hline & & & $\begin{array}{l}\text { Flow index } \\
\text { (30 days) }\end{array}$ & -0.222 & - & - & - \\
\hline & & & Ntot & -0.164 & - & - & - \\
\hline & & & $\begin{array}{l}\text { Radiation } \\
\text { (30 days) }\end{array}$ & -0.039 & - & - & - \\
\hline & $\begin{array}{l}\text { Chlorophyll growth } \\
\text { rate }\end{array}$ & & $\begin{array}{l}\text { Radiation } \\
\text { (30 days) }\end{array}$ & 0.312 & - & - & - \\
\hline & & & Ntot & 0.159 & - & - & - \\
\hline & & & $\begin{array}{l}\text { Flow index } \\
\text { ( } 30 \text { days) }\end{array}$ & -0.050 & - & - & - \\
\hline & & & Ptot & -0.036 & - & - & - \\
\hline \multirow[t]{16}{*}{ Open sites } & AFDM & 0.26 & $\begin{array}{l}\text { Flow index } \\
\text { (30 days) }\end{array}$ & -0.514 & -0.76 & 0.27 & 0.010 \\
\hline & & & $\begin{array}{l}\text { Radiation } \\
\text { (30 days) }\end{array}$ & 0.170 & - & - & - \\
\hline & & & Ntot & 0.081 & - & - & - \\
\hline & & & Ptot & -0.045 & - & - & - \\
\hline & Chlorophyll a & 0.23 & $\begin{array}{l}\text { Radiation } \\
\text { (30 days) }\end{array}$ & 0.479 & 0.015 & 0.006 & 0.017 \\
\hline & & 0.42 & $\begin{array}{l}\text { Flow index } \\
\text { ( } 30 \text { days) }\end{array}$ & -0.453 & -3.397 & 1.287 & 0.003 \\
\hline & & & Ptot & -0.170 & - & - & - \\
\hline & & & Ntot & 0.046 & - & - & - \\
\hline & AFDM growth rate & 0.43 & $\begin{array}{l}\text { Flow index } \\
\text { (30 days) }\end{array}$ & -0.659 & -1.553 & 0.396 & 0.0008 \\
\hline & & & $\begin{array}{l}\text { Radiation } \\
\text { (30 days) }\end{array}$ & 0.304 & - & - & - \\
\hline & & & Ptot & 0.162 & - & - & - \\
\hline & & & Ntot & 0.099 & - & - & - \\
\hline & $\begin{array}{l}\text { Chlorophyll growth } \\
\text { rate }\end{array}$ & 0.37 & $\begin{array}{l}\text { Flow index } \\
\text { (30 days) }\end{array}$ & -0.610 & -6.975 & 2.025 & 0.0026 \\
\hline & & & $\begin{array}{l}\text { Radiation } \\
\text { (30 days) }\end{array}$ & 0.324 & - & - & - \\
\hline & & & Ptot & 0.083 & - & - & - \\
\hline & & & Ntot & -0.052 & - & - & - \\
\hline \multirow{6}{*}{$\begin{array}{l}\text { All sites } \\
\text { (increase } \\
\text { phases) }\end{array}$} & AFDM growth rate & 0.20 & Ptot & 0.453 & 0.003 & 0.001 & 0.006 \\
\hline & & & Ntot & 0.140 & - & - & - \\
\hline & & & $\begin{array}{l}\text { Radiation } \\
\text { (30 days) }\end{array}$ & 0.110 & - & - & - \\
\hline & $\begin{array}{l}\text { Chlorophyll growth } \\
\text { rate }\end{array}$ & & $\begin{array}{l}\text { Radiation } \\
\text { (30 days) }\end{array}$ & 0.224 & - & - & - \\
\hline & & & Ntot & 0.189 & - & - & - \\
\hline & & & Ptot & 0.080 & - & - & - \\
\hline
\end{tabular}




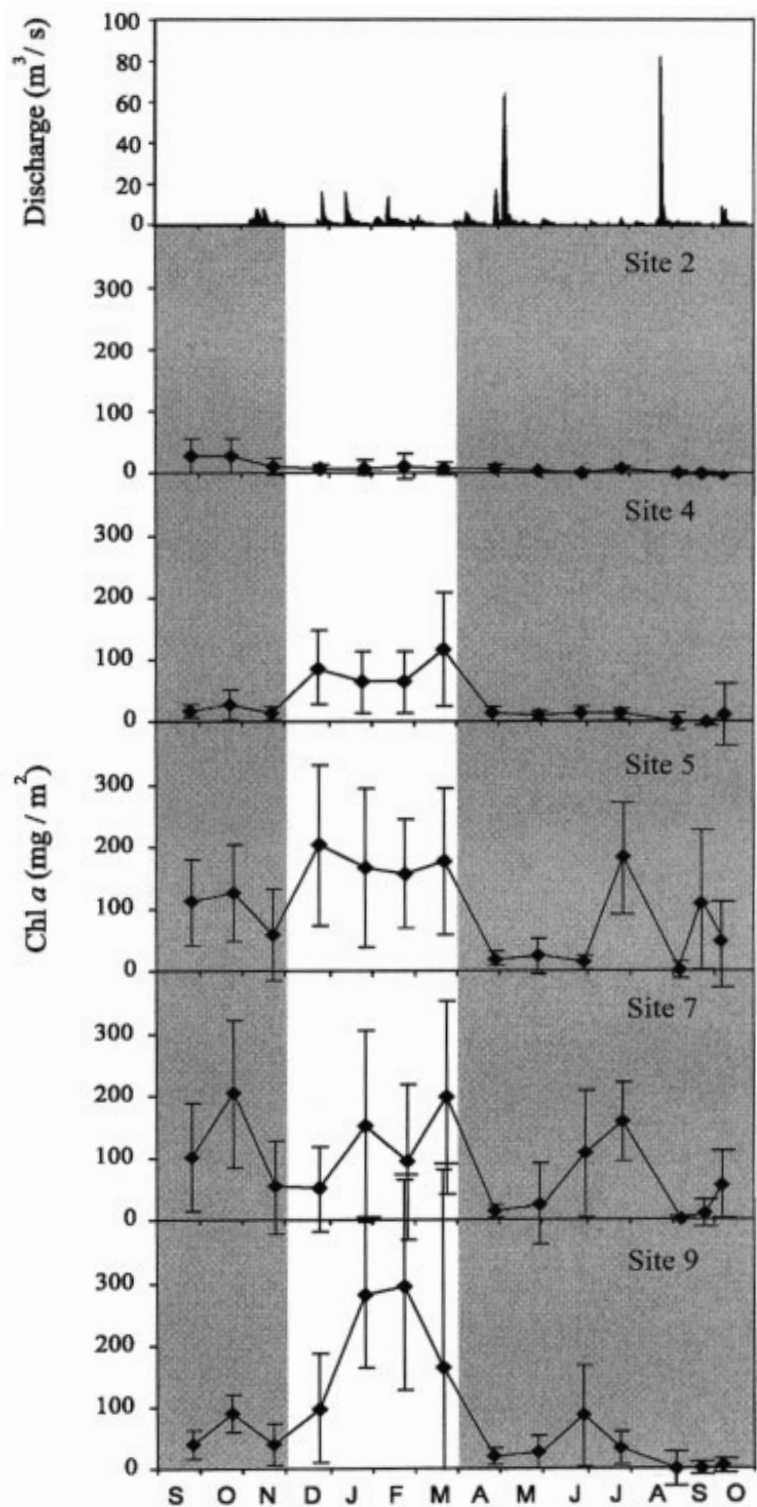

Fig. 3. Periphytic chlorophyll $a$ content at sites 2, 4, 5, 7 and 9 in the Agüera stream, from September 2001 to October 2002. Grey areas mark the period when the riparian forest has leaves. Discharge values registered at site 9 are shown at top.

ked in summer, highest growth occurred at site 5 from June to July $\left(1.73 \mathrm{~g} / \mathrm{m}^{2} \mathrm{~d}\right)$. At site 7 , biomass increases occurred earlier in time and were more gradual. After the decrease in late August flood, periphytic biomass grew again at the open sites, fastest at site 5. Chlorophyll $a$ growth peaks occurred in winter: from November to December at sites 4 and $5\left(2.26 \mathrm{mg} / \mathrm{m}^{2} \mathrm{~d}\right.$,
$4.52 \mathrm{mg} / \mathrm{m}^{2} \mathrm{~d}$ ), and one month later at sites 7 and 9 $\left(3.23 \mathrm{mg} / \mathrm{m}^{2} \mathrm{~d}, 5.70 \mathrm{mg} / \mathrm{m}^{2} \mathrm{~d}\right)$. At the open sites growth also peaked in summer (maxima at site $5,6.37 \mathrm{mg} / \mathrm{m}^{2} \mathrm{~d}$, maxima at site $7,2.87 \mathrm{~g} / \mathrm{m}^{2} \mathrm{~d}$ ) defining a regime like that of biomass. No relevant increase in chlorophyll $a$ was detected at site 2 .

\section{Inter-annual variations}

Flow regimes of the Agüera stream showed large inter-annual differences between 1990 and 2002 (Table 4). Rainfall ranged from $913 \mathrm{~mm}$ in 1991 to $1816 \mathrm{~mm}$ in 2001, this variation resulted in very different hydrographs. 1990 and 2001 were the most stable years, as no bed-moving spate was registered. 1991, 1992 and 1998 were the most torrential years, with 8,16 and 8

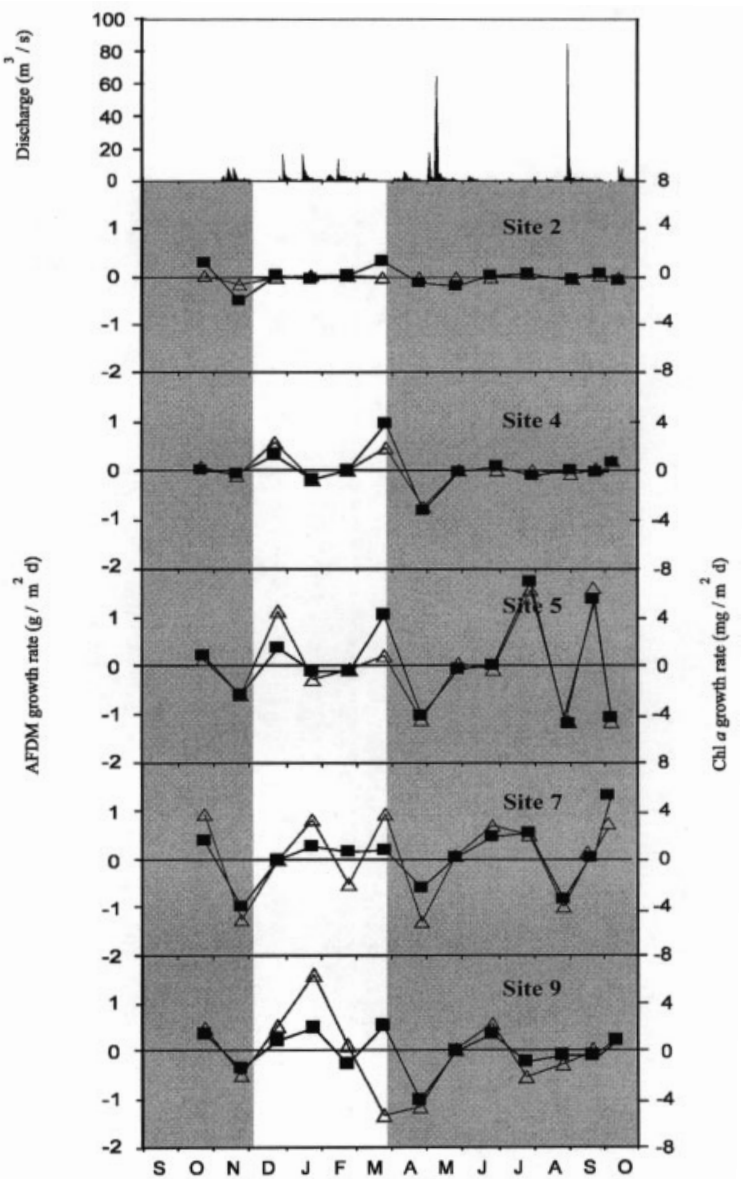

Fig. 4. Periphytic growth, in terms of biomass (dark squares) and chlorophyll a (open triangles), at sites 2, 4, 5, 7 and 9 in the Agüera stream, from September 2001 to October 2002. Grey areas show the period when the riparian forest has leaves. Discharge values registered at site 9 are shown at top. 
Table 4. Flow regimes of the period 1990-2002: average discharge ( $\left.\mathrm{m}^{3} / \mathrm{s}\right)$, number of bed moving spates $\left(>30 \mathrm{~m}^{3} / \mathrm{s}\right)$ and length of recovery periods.

\begin{tabular}{ccccc}
\hline & $\begin{array}{c}\text { Rainfall } \\
(\mathrm{mm})\end{array}$ & $\begin{array}{c}\text { Number of spates } \\
\left(>30 \mathrm{~m}^{3} / \mathrm{s}\right)\end{array}$ & $\begin{array}{c}\text { Longest flood free period } \\
(\text { days })\end{array}$ & $\begin{array}{c}\text { Average discharge } \\
\left(\mathrm{m}^{3} / \mathrm{s}\right)\end{array}$ \\
\hline 1990 & 1353 & 0 & 365 & 1.99 \\
1991 & 913 & 8 & 143 & 4.88 \\
1992 & 1687 & 16 & 102 & 5.28 \\
1993 & 1571 & 7 & 122 & 3.49 \\
1994 & 1487 & 4 & 169 & 3.14 \\
1995 & 1256 & 8 & 300 & 2.86 \\
1996 & 1816 & 8 & 285 & 3.95 \\
1997 & 1287 & 2 & 326 & 2.17 \\
1998 & 1808 & 8 & 156 & 4.50 \\
1999 & 1400 & 3 & 300 & 3.14 \\
2000 & 1480 & 1 & 264 & 3.00 \\
2001 & 919 & 0 & 365 & 2.26 \\
2002 & 1386 & 5 & 128 & 3.21 \\
\hline
\end{tabular}

bed-moving spates respectively. As a result of differences in flood frequency, the duration of stable, baseflow periods allowing periphyton growth showed important inter-annual variations. The longest flood-free period between 1990 and 2002 lasted 750 days (April 2000 - May 2002), whereas in 1992 and 1993 the longest flood-free periods were of only 102 and 122 days respectively. Most flood-free periods occurred in summer, but in 1992, 1993 and 2001 bed-moving spates occurred also in summer. Monthly peak discharge showed low predictability (0.23), constancy (0.00009) and contingency (0.23, Table 5).

Average periphytic biomass at the open sites showed large inter-annual differences $\left(14.1-64.7 \mathrm{~g} / \mathrm{m}^{2}\right.$ at site $5,16.6-44.6 \mathrm{~g} / \mathrm{m}^{2}$ at site 7 ), and was significantly higher in 1990 - 1991 than in 1992 - 1993 and 2001 2002 (ANOVA, $\mathrm{p}<0.05$ ), whereas at the closed site 9 inter annual differences were smaller (13.2 $20.8 \mathrm{~g} / \mathrm{m}^{2}$ ) and not statistically significant (Fig. 5). Chlorophyll $a$ also showed larger inter-annual differences at the open $\left(98.2\right.$ to $329.7 \mathrm{mg} / \mathrm{m}^{2}$ at site $5,86.2$ to $223.4 \mathrm{mg} / \mathrm{m}^{2}$ at site 7$)$ than at the closed sites $(85.7$ to $103.0 \mathrm{mg} / \mathrm{m}^{2}$ at site 9$)$. Differences were statistically significant between 1990 - 1991 and 1992 - 1993 at site 5, and between 1990 - 1991 and 2001 - 2002 at site 7 (ANOVA, $\mathrm{p}<0.05$ ). No significant differences occurred at site 9 . The differences at open reaches followed flow regime. In 1990 no spate occurred from late April to late November, whereas spates were frequent during the other two studies, especially during 1992 -
1993. Flow index was significantly lower during 1990 - 1991 than during either 1992 - 1993 or 2001 - 2002 (paired Student t test, $\mathrm{p}=0.0115, \mathrm{p}=0.0331$ ). Between 1992 - 1993 and 2001 - 2002, flow regime differences were not significant (paired Student t test, $\mathrm{p}=0.1151$ ). At site 9 the effect of discharge on periphyton was low, and the only temporal difference detected was a small increase in biomass following leaf abscission.

\section{Discussion}

Periphyton shows large spatial and temporal varia-

Table 5. Frequency of maximum monthly discharges of the period 1990-2002. Predictability, constancy and contingency indices were calculated (Colwell, 1974).

\begin{tabular}{|c|c|c|c|c|c|c|c|c|c|c|c|c|}
\hline Discharge $\left(\mathrm{m}^{3} / \mathrm{s}\right)$ & $\mathbf{J}$ & F & $\mathbf{M}$ & A & $\mathbf{M}$ & $\mathbf{J}$ & J & $\mathbf{A}$ & 5 & 0 & $\mathbf{N}$ & $\overline{\mathrm{D}}$ \\
\hline $0.04-0.08$ & & & & & & & & 1 & & & & \\
\hline $0.08-0.16$ & & & & & & & & 1 & & & & \\
\hline $0.16-0.31$ & & & & & & & & 3 & & 1 & & \\
\hline $0.31-0.62$ & & & & & & & 2 & 1 & 1 & 1 & & \\
\hline $0.62-1.25$ & & & & & & 2 & 3 & & & 1 & & \\
\hline $1.25-2.50$ & 2 & & 1 & 1 & 1 & 3 & 2 & 2 & 1 & & & 1 \\
\hline $2.50-5.00$ & 1 & 2 & 1 & 1 & 4 & 3 & 3 & 2 & & 2 & & \\
\hline $5.00-10.00$ & 1 & & 3 & 3 & 2 & 4 & 1 & 1 & 4 & 2 & 4 & 1 \\
\hline $10.00-20.00$ & 3 & 7 & 1 & 1 & 2 & & 2 & & 1 & 2 & & 1 \\
\hline $20.00-40.00$ & 4 & 3 & 3 & 2 & 1 & & & 1 & & 2 & 6 & 5 \\
\hline $40.00-80.00$ & 2 & 1 & 2 & 4 & 3 & & & & 2 & & 2 & 2 \\
\hline $80.00-160.01$ & & & 1 & 1 & & 1 & & 1 & & 2 & 1 & 3 \\
\hline
\end{tabular}



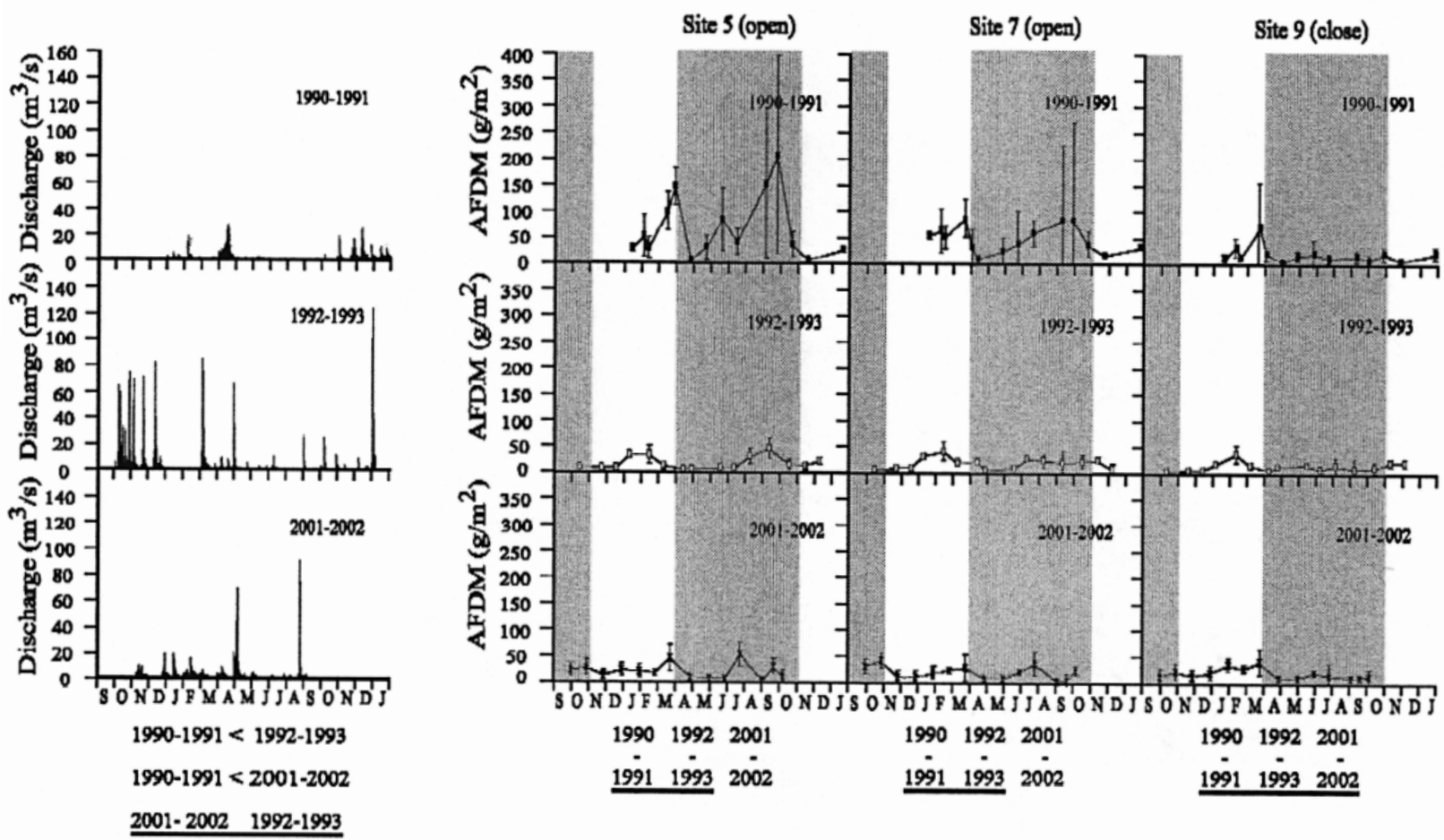

Fig. 5. Periphytic biomass at sites 5, 7 and 9 and discharge at site 9, in the 1990-1991, 1992-1993 and 2001-2002 study periods. Grey areas mark the period where the riparian forest has leaves. Under the graphs, results of Paired Student t Test (for discharge) and ANOVA (for biomass).

tions in the Agüera stream. Previous work (López de Luzuriaga 1995, Elósegui \& Pozo 1998) suggested that spatial differences depended mainly on canopy cover, nutrient content and substrate stability, whereas spates were the main source of temporal variations, seasonality being low. The present study allows us to measure more precisely the importance of some environmental variables, and to put seasonal variations in a wider inter-annual context.

Four out of the present study's 5 sites were also studied in 1990 - 91 by Elósegui \& Pozo (1998), and the other (site 4) was a reach just downstream from their site 4. Only our 3 downstream sites coincide with the work of López de Luzuriaga (1995), carried out during 1992 - 93. Despite the coincidence of sites and the agreement in the main trends detected, there were also interesting differences in the physico-chemical characteristics of the studied reaches. Compared to Elósegui \& Pozo (1998), our pH values showed lower averages, and especially lower peak values. For instance, in 1990 - $91 \mathrm{pH}$ values up to 9.80 occurred at site 5 , and up to 9.50 at site 7 , whereas during 2001 - 02 maxima were 8.45 and 8.15 respectively. This is a remarkable diffe- rence, especially because human activities around sites 5 and 7 remain fairly unchanged. Thus, the difference seems to reflect the lower discharges and much longer flood-free periods, that allowed for a great development of periphyton at sites 5 and 7 (Elósegui \& Pozo 1998), whose strong photosynthetic activity resulted in diel $\mathrm{pH}$ variations of up to two units (Elósegui \& Pozo 1994). Lower periphytic activity seems also responsible for the higher nitrogen concentrations (especially higher summer maxima) measured at sites 5 and 7 in the present study, as during 1990 - 91 periphyton in the Agüera mid-reaches showed an extremely high capacity to retain nutrients (Elósegui et al. 1995). Phosphate concentrations were less different between the present study and Elósegui \& Pozo (1998), with the exception of the marked decrease at site 9 , probably because the improving of sewage systems in Guriezo during the last years. Another remarkable difference is a decrease in canopy cover at site 2 (from 86.7 to $70.1 \%$ ), as a result of the harvest of a forest beyond the riparian area, and the marked increase in cover (from 8.5 to $48 \%$ ) at site 5 , due to the growth of the small riparian trees.

The mild, oceanic climate of the study area results in 
low seasonality of the phyisico-chemical characteristics of stream water, temporal variations being mainly produced by floods (Elósegui et al. 1997) that can occur at any season of the year (Elosegi et al. 2002). On the other hand, radiation could be an important source of seasonality for periphyton, because it changes throughout the year with day length and sun height over the horizon (Strahler \& Strahler 1991). Nevertheless, the seasonality of solar radiation is far from clear. During the present study, a sunny winter and a cloudy summer resulted in very similar average daily radiation during these seasons, and the large differences in riparian cover at sites 4 and 9 (closed canopy but unconstrained channel) resulted in much more sunlight reaching the streambed during winter. Differences were much reduced at the open sites and at site 2 , where cover does not change very much during the year because of topographic constraints. On the other hand, during the 2000 - 01 season summer radiation averaged 2.6 times higher than winter values (unpublished data), thus resulting in significantly higher summer radiation at sites 2,5 and 7 , and non-significant differences at sites 4 and 9 . Thus, the growth and abscission of leaves marks strong seasonality of essential resources for periphyton at some reaches but not at some others, but this pattern can change from year to year in function of weather. Periphytic biomass will likely show larger differences between open and closed reaches in years with sunny summers and cloudy winters.

Spatial differences of periphytic biomass at the present study were much lower than those measured by Elósegui \& Pozo (1998) in 1990 - 91, but the main spatial patterns were consistent: values were lowest at site 2 and highest at sites 5 and 7 . Seasonal differences were low, but the same patterns were also discernable: low periphytic biomass at site 2 throughout the year, winter maxima at site 9 , and multiple peaks throughout the year (both summer and winter) at sites 5 and 7 .

Many papers dealt with the environmental factors controlling the abundance of stream periphyton. Some stress the effect of flood size and frequency (Mosisch \& Bunn 1997, Uehlinger 1991), some others light availability (DeNicola et al. 1992, Hill et al. 1995, 2001), nutrients (Biggs 1995, 2000), substrate stability (Biggs \& Gerbeaux 1993) or grazing intensity (Kjeldsen 1996, Rosemond et al. 2000). Obviously, adequate substrate, light and nutrients are important resources for periphyton, and both floods and grazers can decrease periphytic abundance, but the most relevant factors will likely depend on the studied system as well as on the spatial and temporal scale of the study.
As expression of temporal variability, floods are important disturbances for periphyton, as they scour and reset algal biomass to very low values (Mosisch \& Bunn 1997). Therefore, flood-prone streams usually have low periphytic biomass (Uehlinger et al. 1996). Nevertheless, the effect of floods on periphyton can be modulated by substrate stability, communities on fine substrata being most affected. Elósegui \& Pozo (1998) showed that floods over $30 \mathrm{~m}^{3} / \mathrm{s}$ scoured most periphyton along the Agüera stream, and that communities at site 7 seemed to have greater resistance against floods below $30 \mathrm{~m}^{3} / \mathrm{s}$. During 2001 - 2002, three floods around $20 \mathrm{~m}^{3} / \mathrm{s}$ occurred in winter, but their effect on periphyton was almost nil. Therefore, although the effect of large floods on periphytic biomass seems clear, the effect of smaller floods can change, probably depending on the growth-form of the dominant algae (Grimm \& Fisher 1989, Peterson 1996a). Encrusting and prostrate algae are more resistant than filamentous ones, especially more than diatom filaments (Biggs \& Thomsen 1995, Peterson \& Stevenson 1990). After winter flows unicellular diatoms dominated, although filamentous diatoms (Melosira varians C. Agardh) also were abundant (unpublished data). Our sampling dates of winter were 7 - 9 days after floods. Unicellular diatoms are resistant to most flows, even their growth is stimulated by current increases (Stevenson 1990). Apparently, at least propagules of filamentous diatoms remained also.

Not all drops of periphytic biomass are caused by floods. In the present study a large decrease of periphyton was detected at the end of April, in absence of any high discharge, and Elósegui \& Pozo (1998) detected a similar decrease in October 19991. In neither case were snails nor other grazers particularly abundant in the stream, and thus, Elósegui \& Pozo (1998) suggested that this drop was caused by the disappearance of summer species and the slower appearance of winter species, as has been reported for other streams (Necchi et al. 1991). A similar change in the community structure could be the responsible of the April drop in periphyton detected in the present study (Acs \& Kiss 1993). April and October are periods of quick changes in stream ambient conditions (especially light and temperature), which under baseflows could drive shifts on periphytic communities. In the Agüera, coinciding with the biomass decrease at the end of April, most unicellular diatoms disappeared and unicellular and parenchimatous greens appeared (unpublished data).

Algal scouring, whatever its cause, produces free space to colonize, and provided that essential re- 
sources are available, promotes periphytic growth (Peterson 1996b). Usually growth is fastest in open, nutrient-rich reaches (Rosemond 1993, Biggs \& Close 1989) and in 1990 - 91 very high stream metabolism and periphytic growth were measured (Elósegui \& Pozo 1998). In this study we observed that AFDM growth was significantly correlated with phosphate content during increase phases. The highest daily increase of periphytic AFDM during the present study $\left(1.73 \mathrm{~g} / \mathrm{m}^{2}\right.$ d) was detected at site 5 in summer, and was well below the $3.71 \mathrm{~g} / \mathrm{m}^{2} \mathrm{~d}$ reported by Elósegui \& Pozo (1998) for June, thus showing that environmental conditions for periphyton were in general poorer during 2001 - 02. As nutrient and substrate characteristics remained much unchanged, we suspect that clouded skies were responsible for this relatively low productivity.

Stepwise regressions between environmental variables and periphyton showed differences for open and closed reaches. At open sites, flow was determinant of the periphyton dynamics, while light availability was more relevant at the closed sites. Thus, the main factors responsible for periphytic abundance differed depending on canopy cover, reflecting the fact that seasonal variations in light availability depend on riparian cover (Hill et al. 2001), and that at closed sites this could override the effect of floods. A similar result was reported by Robinson \& Minshall (1986) who studied the effects of disturbance frequency on periphyton in Mink Creek (Idaho). At sites with closed canopy no disturbance effect was apparent, whereas at open canopy sites periphytic standing crop increased significantly as disturbance frequency decreased. It is remarkable that no nutrient-related variable entered our models, thus suggesting that periphyton in the Agüera stream is more often limited by light than by nutrient availability.

From a longer temporal perspective, our data show large inter-annual variations in periphytic biomass. The narrow, steep basin and the short channels of the Aguiera stream interact with the rainy weather to produce a torrential discharge regime, with spates occurring at any time of the year, although less frequently during summer (Elosegi et al. 2002). This makes flood predictability and seasonality low. Furthermore, some years many bed-moving spates occur, whereas some others register no spate at all, and thus, monthly peak discharge shows low constancy and contingency. In flood-prone streams the seasonality of periphytic biomass is truncated (Biggs \& Close 1989, Fisher and Grimm 1988, Uehlinger et al. 1996), as periphytic growth depends mainly on discharge. Inter annual pat- terns may vary distinctly. Uehlinger (2000), using a dynamic model, showed that in a river with a flashy flow regime, annual biomass patterns were extremely variable and not predictable. However, over the longterm (more than one annual cycle) biomass was relatively constant. In the Agüera stream biomass seems not so constant, probably because in flood-free years nutrient levels allow for very high abundance of periphyton.

In the Agüera stream, abundance of floods during the year controls the periphytic development at open sites, but less so at closed ones. Thereby, periphytic abundance showed high inter-annual changes. At the open sites 5 and 7, periphyton was much more abundant in 1990 - 1991 than in either 1992 - 1993 or 2001 - 2002, reflecting the absence of bed-moving spates during 1990 - 1991. Meantime, at the closed site 9 the inter-annual differences in flood frequency did not affect periphyton abundance, and there canopy cover defined a marked seasonal pattern that changed much less inter-annually. Furthermore, high- and lowbiomass years do not coincide at open and closed reaches, thus stressing their different behaviour.

In summary, periphyton dynamics are different depending on canopy cover. At the open canopy sites spates determine the temporal periphytic patterns, and in torrential systems like the Agüera inter-annual variations of periphytic abundance are large and unpredictable, and depending on the hydrologic regime spatial variations between sites also change. On the other hand, at the closed sites the phenology of the riparian deciduous forest controls periphyton abundance, overriding the effect of other factors. Therefore, studies on periphyton should take in account inter-annual variability, especially where high periphytic abundance can be expected, i.e., at sites with high availability of light and nutrients.

\begin{abstract}
Acknowledgements
This work has been supported by the research projects PIGV 8924 (Basque Government), 9/UPV00118.310-14476/2002 (University of the Basque Country), DGICYT PB459/92 and MCYT BOS2003-04466 (Spanish Government). Arantzazu Lopez de Luzuriaga did most of the 1992-93 work. Discharge data were gently provided by the Spanish Northern Hydrographical Confederation, and solar radiation data by the Spanish Meteorological Institute. Oihana Izagirre did part of this work thanks to a pre-doctoral grant by the Basque Government. Dr. Sergi Sabater made many interesting comments on a early draft of this paper.
\end{abstract}

\section{References}

Acs E. \& Kiss K.T. 1993. - Colonization processes of diatoms on artificial substrates in the River Danube near Budapest (Hungary). Hydrobiologia, 269, 307-315. 
APHA (American Public Health Association). 1992. - Standard methods for the examination of water and wastewater. 18th edition. American Public Health Association, Washington, D.C., USA.

Biggs B.J.F. \& Close M.E. 1989. - Periphyton biomass dynamics in gravel bed rivers: the relative effects of flows and nutrients. Freshwat. Biol., 22, 209-231.

Biggs B.J.F. \& Gerbeaux P. 1993. - Periphyton development in relation to macro-scale (geology) and micro-scale (velocity) limiters in two gravel-bed rivers, New Zealand. N. Z. J. Mar. Freshwat. Res., 27, 39-53.

Biggs B.J.F 1995. - The contribution of disturbance, catchment geology and landuse to the habitat template of periphyton in stream ecosystems. Freshwat. Biol., 33, 419-438.

Biggs B.J.F \& Thomsen H.A. 1995. - Disturbance of stream periphyton by perturbations in shear stress: time to structural failure and differences in community resistance. J. Phycol., 31, 233-241.

Biggs B.J.F, Kilroy C. \& Lowe R.L. 1998. - Periphyton development in three valley segments of a New Zealand grassland river: test of a habitat matrix conceptual model within a catchment. Arch. Hydrobiol., 143, 147-177.

Biggs B.J.F. 2000. - Eutrophication of streams and rivers: dissolved nutrient-chlorophyll relationships for benthic algae. J. N. Am. Benthol. Soc., 19, 17-31.

Colwell R.K. 1974. - Predictability, constancy, and contingency of periodic phenomena. Ecology, 55, 1148-1153.

DeNicola D.M., Hoagland K.D. \& Roemer S.C. 1992. - Influences of canopy cover on spectral irradiance and periphyton assemblages in a prairie stream. J. N. Am. Benthol. Soc., 11, 391-404.

Díez J.R., Elosegi A. \& Pozo J. 2001. - Woody debris in north Iberian streams, Influence of geomorphology, vegetation and management. Environ. Manage, 28, 687-698.

Elósegi A., Basaguren A. \& Pozo J. 2002. - Ecology of the Agüera, a review of fourteen years of research in a Basque stream. Munibe., 53, 15-38.

Elósegui A. \& Pozo J. 1994. - Spatial versus temporal variability in the physical and chemical characteristics of the Agüera stream (North Spain). Acta Oecol., 15, 543-559.

Elósegui A., Arana X., Basaguren A. \& Pozo J. 1995. - Self-purification process along a medium-sized stream. Environ. Manage. 19, 931-939.

Elósegui A., González E., Basaguren A. \& Pozo J. 1997. - Water quality variability in the Agüera stream watershed at different spatial and temporal scales. Pages 55-68 in International River Water Quality. Pollution and Restoration. Best G.A., Bogacka T. \& Niemrycz E. (eds). E \& FN Spon, London.

Elósegui A. \& Pozo J. 1998. - Epilithic biomass and metabolism in a north Iberian stream. Aquat. Sci., 60, 1-16.

Eulin A. \& Le Cohu R. 1998. - Epilithic diatom communities during the colonization of artificial substrates in the River Garonne (France). Comparasion with the natural communities. Arch. Hydrobiol., 143, 79-106.

Fisher S.G. \& Grimm N.B. 1988. - Disturbance as a determinant of structure in a Sonoran desert stream ecosystem. Verh. Internat. Verein. Limnol., 23, 1183-1189.

Grimm N.B. \& Fisher S.G. 1989. - Stability of periphyton and macroinvertebrates to disturbance by flash floods in a desert stream. J. N Am. Benthol. Soc. 8(4), 293-307.

Hill W.R., Ryon M.G. \& Schilling E.M. 1995. - Light limitation in a stream ecosystem: responses by primary producers and consumers. Ecology, 76, 1297-1309.
Hill W. R., Mulholland P.J. \& Marzolf E.R. 2001. - Stream ecosystem responses to leaf emergence in spring. Ecology, 82, 23062319.

Kjeldsen K., Iversen T.M., Thorup J. \& Winding T. 1998. - Benthic algal biomass in an unshaded first-order lowland stream: distribution and regulation. Hydrobiologia, 377, 107-122.

López de Luzuriaga A. 1995. - Perifitonaren dinamika eta kolonizazioa Agüera errekan. MsC Thesis. UPV / EHU.

Mosisch T.D. \& Bunn S.E. 1997. - Temporal patterns of rainforest stream epilithic algae in relation to flow-related disturbance. Aquat. Bot., 58, 181-193.

Necchi Jr. O., Dip M.R. \& Goes R.M. 1991. - Macroalgae of a stream in southeastern Brazil: composition, seasonal variation and relation to physical variables. Hydrobiologia, 213, 241-250.

Peterson C.G. \& Stevenson R.J. 1990. - Post-spate development of epilithic algal communities in different current environments. Can J. Bot., 68, 2092-2102.

Peterson C.G. 1996a. - Response of benthic algal communities to natural physical disturbance. Pages 375-402 in Algal ecology: Freshwater benthic ecosystems. Stevenson R.J., Bothwell M.L. \& Lowe R.L. (eds.), Academic Press, San Diego.

Peterson C.G. 1996b. - Mechanisms of lotic microalgal colonization following space-clearing disturbances acting at different spatial scales. Oikos, 77, 417-435.

Robinson C.T. \& Minshall G.W. 1986. - Effects of disturbance frequency on stream benthic community structure in relation to canopy cover and season. J. N. Am. Benthol. Soc., 5, 237-248.

Rosemond A.D. 1993. - Interactions among irradiance, nutrients, and herbivores constrain a stream algal community. Oecologia, 94, 585-594.

Rosemond A.D., Mulholland P.J. \& Brawley S.H. 2000. - Seasonally shifting limitation of stream periphyton: response of algal populations and assemblage biomass and productivity to variation in light, nutrients, and herbivores. Can. J. Fish. Aquat. Sci., 57, 6675.

Sartory D.P. \& Grobbelaar J.E. 1984. - Extraction of chlorophyll $a$ from freshwater phytoplankton for spectrophotometric analysis. Hydrobiologia, 114, 177-187.

Shortreed K.R.S. \& Stockner J.G. 1983. - Periphyton biomass and species composition in a coastal rainforest stream in British $\mathrm{Co}-$ lumbia: effects of environmental changes caused by logging. Can. J. Fish. Aquat. Sci., 40, 1887-1895.

Steinman A.D., Mulholland P.J., Palumbo A.V., Flum T.F., Elwood J.W. \& DeAngelis D.L. 1990. - Resistance of lotic ecosystems to a light elimination disturbance. Ecology, 72, 1299- 1313.

Stevenson R.J. 1990. - Benthic algal community dynamics in a stream during and after a spate. J. N. Am. Benthol. Soc., 9, 277 288.

Strahler A.N. \& Strahler A.H. 1991. - Modern Physical Geography. $3^{\text {rd }}$. ed. John Wyley \& Sons, Inc. New York, USA.

Uehlinger U. 1991. - Spatial and temporal variability of the periphyton biomass in a prealpine river (Necker, Switzerland). Arch. Hydrobiol., 123, 219-237.

Uehlinger U., Bührer H. \& Reichert P. 1996. - Periphyton dynamics in a floodprone prealpine river: evaluation of significant processes by modelling. Freshwat. Biol., 36, 249-263.

Uehlinger U. 2000. - Periphyton biomass in an unpredictable environment: exploring the temporal variability with a dynamic model. Verh. Internat. Verein. Limnol., 27, 3162-3165. 